\title{
Towards a decentralised European Public Prosecutor's Office?
}

\author{
by Simone White and Nicholas Dorn
}

A rticles 85 and 86 of the Treaty on the Functioning of the European Union appear in the chapter on judicial cooperation in criminal matters of the Treaty on the Functioning of the European Union (OF (2008) J C 115, Consolidated versions of the Treaty on European Union and the Treaty on the Functioning of the European Union). They deal with the possible extension of Eurojust's powers and with the creation of a European Public Prosecutor's Office (EPPO). Eurojust was set up by Council Decision 2002/187/JHA (OJ (2002) L 63/1) as a body of the European Union with to stimulate and to improve coordination and cooperation between competent judicial authorities of the Member States. This Decision was subsequently amended by Council Decision 2003/659/JHA (OJ (2003) L 245/44) and Council Decision 2009/426/JHA (OJ (2009) L 138/14.

Many scenarios have been advanced for the implementation of Articles 85 and 86 TFEU. This brief overview of the topic argues that a step by step approach should be possible, with a half-way house between coordination and a purely vertical, centralised model. Three possible implementations are summarised in Table 1 below and are discussed in the following sections of the paper. It is necessary to give some legal, research and historical background. However, it is not the aim here to discuss the level of criminal law harmonisation necessary before these EPPO variants could be set up; neither is accountability discussed here, as this topic would in itself warrant discrete treatment. The highly dynamic nature of European law and European Criminal Law in particular has been taken for granted here: see V Mitsilegas, (2009), European Criminal Law - Modern studies in European Law, Hart Publishing; A Klip (2009) European Criminal Law: An integrative approach, Antwerp, Oxford, Portland: Intersentia (http://www.intersentia.be/), Ius Communitatis, vol 2, 2009.

\section{ARTICLE 85: EUROJUST REINFORCED OR DECENTRALISED EPPO}

Article 85(1) TFEU confirms the horizontal cooperation role of Eurojust: its mission is to support and strengthen coordination and cooperation between national investigating and prosecuting authorities in relation to serious crime affecting two or more Member States or requiring a prosecution on common bases, on the basis of operations conducted and information supplied by the Member States' authorities and by Europol. This enshrines Eurojust's role in the Treaty and opens up possibilities:

In this context, the European Parliament and the Council by means of regulations adopted in accordance with the ordinary legislative procedure shall determine Eurojust's structure, operation, field of action and tasks. These tasks may include:

(a) the initiation of criminal investigations, as well as proposing the initiation of prosecutions conducted by competent national authorities, particularly those relating to offences against the financial interest of the Union;

(b) the coordination of investigations and prosecutions referred to in point (a);

(c) the strengthening of judicial cooperation, including by resolution of conflicts of jurisdiction and by close cooperation with the European Judicial Network.

Those regulations shall also determine arrangements for involving the European Parliament and national Parliaments in the evaluation of Eurojust's activities.

Article 85(2) clarifies that in the prosecutions referred to in paragraph 1 , and without prejudice to Article 86, formal acts of judicial procedure shall be carried out by the competent national officials. Article 85(2) however does not indicate the type of relationship there should be between the initiator of criminal investigations and prosecutions related to the financial interests of the European Union and the competent national authorities. The future structure of Eurojust is therefore left open.

Article 85 TFEU however makes it clear that although Eurojust's general powers may be reinforced as far as coordination and the resolution of conflicts is concerned, in relation to offences against the financial interests of the EU Eurojust may be granted a power to initiate investigations or prosecutions in the future. Eurojust 
Table 1: Possible implementations of Articles 85 or 86 TFEU in relation to the investigation and prosecution of crimes to the detriment of the financial interests of the EU

\begin{tabular}{|c|c|c|c|c|}
\hline Models & $\begin{array}{l}\text { New powers/ } \\
\text { structure }\end{array}$ & Institution-building & \begin{tabular}{|l} 
European \\
Criminal Law
\end{tabular} & \begin{tabular}{|l} 
Possible \\
advantages / \\
disadvantages
\end{tabular} \\
\hline $\begin{array}{l}\text { Model 1: } \\
\text { A reinforced } \\
\text { Eurojust. Art } 85 \text { TFEU } \\
\text { (progressive increase } \\
\text { of powers). }\end{array}$ & $\begin{array}{l}\text { Reinforced coordination; } \\
\text { no major changes to } \\
\text { structure }\end{array}$ & $\begin{array}{l}\text { No new institution; } \\
\text { Eurojust is consolidated }\end{array}$ & $\begin{array}{l}\text { Continued focus on } \\
\text { mutual recognition }\end{array}$ & $\begin{array}{l}\text { Close to the present } \\
\text { development path of } \\
\text { Eurojust. Politically } \\
\text { palatable. But might not be } \\
\text { much more effective than } \\
\text { current arrangements? }\end{array}$ \\
\hline $\begin{array}{l}\text { Model 2: } \\
\text { Decentralised EPPO. } \\
\text { Based on national } \\
\text { resources (not "over" } \\
\text { them): horizontal } \\
\text { integration. } \\
\text { Art } 85 \text { TFEU at first, } \\
\text { making evolution } \\
\text { towards a more } \\
\text { centralised model } \\
\text { under Art 86TFEU } \\
\text { possible }\end{array}$ & $\begin{array}{l}\text { Reinforced cooperation. } \\
\text { Heads of national authorities } \\
\text { are appointed as national } \\
\text { EPPs. At EU level they } \\
\text { form a college, with a } \\
\text { rotating chair. No } \\
\text { over-arching 'head' at } \\
\text { European level. }\end{array}$ & $\begin{array}{l}\text { A political choice here: } \\
\text { whether the decentralised } \\
\text { entity is designated as an } \\
\text { Institution - or simply has } \\
\text { a secretariat and facilities } \\
\text { within Eurojust/elsewhere. }\end{array}$ & $\begin{array}{l}\text { Focus both on mutual } \\
\text { recognition and } \\
\text { harmonisation. }\end{array}$ & $\begin{array}{l}\text { Possibly the best basis for } \\
\text { operational cooperation. } \\
\text { However not widely } \\
\text { discussed. Could be seen as } \\
\text { a "spoiler" for models } \\
1 \text { and } 2 \text {. }\end{array}$ \\
\hline $\begin{array}{l}\text { Model 3: } \\
\text { A centralised EPPO } \\
\text { Art } 86 \text { TFEU. } \\
\text { Vertical integration. } \\
\text { Original Corpus Juris. }\end{array}$ & $\begin{array}{l}\text { Reinforced cooperation. } \\
\text { The EPPO appoints certain } \\
\text { national prosecutors as } \\
\text { EEPs, subordinated to a } \\
\text { central European office. } \\
\text { Europol and OLAF also } \\
\text { work for the central } \\
\text { EPPO, staffed by } \\
\text { EU officials. }\end{array}$ & $\begin{array}{l}\text { A new, central institution } \\
\text { created "from Eurojust", } \\
\text { financed from the } \\
\text { EU budget. }\end{array}$ & $\begin{array}{l}\text { Maximum harmonisation } \\
\text { of criminal law. }\end{array}$ & $\begin{array}{l}\text { Considerable symbolic } \\
\text { significance. Political } \\
\text { resistance. Not all Member } \\
\text { States involved. } \\
\text { Queries over } \\
\text { effectiveness. }\end{array}$ \\
\hline
\end{tabular}

would initiate investigations and prosecutions, whilst competent national officials would carry out formal acts of judicial procedure. At present, Eurojust may request (authors' emphasis) the competent authorities of the Member States concerned, giving its reasons, to: (i) undertake an investigation or prosecution of specific acts; (ii) accept that one of them may be in a better position to undertake an investigation or to prosecute specific acts; (iii) coordinate between the competent authorities of the Member States concerned; (iv) set up a joint investigation team in keeping with the relevant cooperation instruments; (v) provide it with any information that is necessary for it to carry out its tasks; (vi) take special investigative measures; (vii) take any other measure justified for the investigation or prosecution (Art 6 of Council Decision 2009/426/JHA)

Article 17(7) of the Framework Decision on the European Arrest Warrant also requires Member States to notify Eurojust whenever they cannot execute a warrant on time (Council Framework Decision of 13 June 2002 on the European Arrest Warrant and the surrender procedures between Member States, 2002/584/JHA, OJ
(2002) L 190/1). Eurojust can also advise in situations where there are multiple conflicting arrest warrants (Art 16(2)).

It is not clear how successful Eurojust has been in the past in obtaining (authors' emphasis) that an investigation or prosecution be undertaken by a Member State authority. Zwiers has explored this issue.

Although neither the national members nor the College can properly initiate prosecutions under the Eurojust Decision, the agency's requests cannot be refused by the Member States without them owing an explanation (save for reasons of national security or hampering ongoing investigations). The former Eurojust President called Eurojust an "empowered" network because of this semiauthority that its requests have. It is also suggested that Eurojust could seek political pressure on uncooperative Member States' authorities by including data on compliance with its requests in its annual reports (see M Zwiers, (2011), The European Public Prosecutor's Office analysis of a multi-level criminal justice system, Intersentia, p 260). 
However, Zwiers goes on to add that such requests were rare. In 2007, one request to investigate/prosecute and one request to cede jurisdiction were made by a national member, and one request to cede jurisdiction was made by the College.

How easy would it be for Eurojust to initiate investigations or prosecutions? Eurojust's national members are seconded from the EU Member States. Neither national members nor the College have the power to investigate, prosecute or bring to judgement the suspects of criminal offences with a trans-national dimension. To formally initiate criminal investigations, one supposes that Eurojust would need to have access to its own criminal investigation resources. At present Europol only deals with information, whilst OLAF, a European Commission Directorate-General, carries out administrative investigations to further the protection of the financial interests of the European Union. Were investigation resources to be subordinated to Eurojust, so that it could initiate investigations and prosecutions, then Eurojust could become an EPPO of a sort under Article 85 (1) (a) TFEU. Some changes might also be discussed in relation to Eurojust's partners, Europol and OLAF, as part of the package. A legislative initiative on criminal law protection and another on the administrative and criminal law cooperation between competent national authorities including OLAF have already been planned for the period leading up to 2013.

Given the wording of Article 85 TFEU, it is possible to conceive of a Eurojust with reinforced powers under Article 85(1) (b) and (c) only (as a first step). It would entail a progressive reinforcement of Eurojust with respect to coordination and the resolution of conflicts, whilst the initiation of investigations and prosecutions would be left to a later date, as soon as supporting legislation can be put in place, when this would add value to the function or coordination of criminal investigations and prosecutions currently exercised by Eurojust. The protection of the financial interests of the EU could benefit from a general reinforcement of Eurojust under Article 85(1)(b) and (c). Eurojust could also start monitoring responses to the requests to investigate or to prosecute it sends to Member States' authorities. This would be a cautious rather than an adventurous approach, which could leave space for future development (see model 1 in Table 1).

Another possibility can be envisaged under Article 85 TFEU: a decentralised EPPO. Model 2 is briefly outlined, focusing on the designation of existing heads of prosecution services as Members of the EPPO - supported by a deputy and staff with full powers to divert all the resources of national prosecution services. This would dissolve some of the difficulties inherent in arrangements which, whilst they might have powers in formal terms, are institutionally and operationally disembodied. Admittedly, model 2 could simply follow on from model 1. The central coordinating EPPO would not carry out investigations of its own and would not therefore be subjected to judicial review, unlike an EPPO set up under Article 86 TFEU (see model 3). As Inghelram pointed out:

"It is assumed that, in line with Article 86(2) TFEU, an EPPO will itself be responsible for carrying out investigations, even if coercive measures related to these investigations will be carried out by other authorities. Individuals affected by acts performed during such investigations therefore seem entitled, for the purposes of judicial review, to consider that, as a general rule, they are affected by acts of the EPPO itself. The situation would be different if an EPPO only had the power to coordinate investigations carried out by others, or the power to propose or suggest to other authorities that investigations be carried out" (J F H Inghelram, (2011), Legal and Institutional Aspects of the European Anti-Fraud Office (OLAF:) An analysis with a look forward to a European Public Prosecutor's Office, Europa Law Publishing, pp $263-$ 64).

\section{ARTICLE 86: CREATION OF A (VERTICAL) EUROPEAN PUBLIC PROSECUTOR'S OFFICE}

The first paragraph of Article 86 states that, in order to combat crimes affecting the financial interests of the Union, the Council, by means of regulations adopted with a special legislative procedure, may establish a European Public Prosecutor's Office from Eurojust. "From Eurojust" opens up a number of possibilities. The 2004 House of Lords enquiry on the EPP opined that (a) the EPP should oversee Eurojust; (b) that Eurojust itself would take on the role of the European Public Prosecutor; or that the European Public Prosecutor, while a separate body, would join the Eurojust College as an extra member. Eurojust's competence being much wider than the proposed initial competence of the EPP, it is however unlikely that the latter would oversee the former.

Current thinking in EU policy circles is that:

(i) the development of Eurojust and the creation of an EPPO could go on in parallel;

(ii) a step by step approach could include first evaluating the revised Eurojust decision, exploring further the developments under Article 85 TFEU and then discussing the establishment of an EPPO from Eurojust in accordance with Article 86;

(iii) it would also be possible to set up a new institution to be only loosely connected to Eurojust.

In any case, there would be a link with Eurojust.

Article 86 also provides that the Council shall act unanimously after obtaining the consent of the European Parliament. This renders the creation of an EU-wide EPPO unlikely as some Member States are reluctant and/or would have to opt in and/or submit an EPPO proposal to referendum. However, Article 86 goes on to say that in the absence of unanimity in the Council, a group of at least nine Member States may request that the draft regulation 
be referred to the European Council. In that case, the procedure in the Council would be suspended. After discussion, and in case of a consensus, the European Council would then refer the draft back to the Council for adoption within four months.

It is unclear at present whether there might be nine Member States interested in going forward, although Belgium, Luxembourg, The Netherlands and Spain have expressed interest recently. However, the nine Member States "reinforced cooperation" scenario seems the most likely and could proceed on the basis of Articles 20(2) and 329(1) TEU.

A number of key issues have been raised. One issue is of knowing whether there is a sufficient level of mutual recognition and of harmonisation of criminal law and procedure to enable an EPPO to function. Another issue concerns the articulation of activities of the European Public Prosecutor's Office with the investigation and prosecution authorities of the Member States and with its EU partners, Europol and OLAF. In this a quick retrospective may assist.

\section{FLASHBACK: THE ORIGINAL PROPOSAL FOR A EUROPEAN PUBLIC PROSECUTOR}

The original, classic and ideal model of a European Public Prosecutor (EPP) can be found in the Corpus Juris study, directed by Delmas-Marty and published in 1997and in a subsequent follow-up study in 2000 (see M DelmasMarty, (1997), Corpus Juris introducing penal provisions for the purpose of the financial interests of the European Union, Economica, Paris, and also House of Lords, Prosecuting Fraud on the Community's finances - the Corpus Juris, 9th Report, 1998-99, HL Paper 62; and further, M DelmasMarty and J A E Vervaele, (2000), The implementation of the Corpus Juris in the Member States, Intersentia, Oxford, four volumes) In these early studies, a central EPP was envisaged (based on the French prosecuting model), with subordinated, delegated European Public Prosecutors responsible for the investigation and prosecution of EU fraud in the EU Member States.

These delegated prosecutors would wear two hats, in the sense that they would apply national law in national cases, but would apply another set of EU-wide substantive and procedural criminal law rules for offences affecting the EU budget found in the Corpus Juris. The EPP would be independent from the Member States' governments and would have the authority to act on her own initiative. The procedure for appointment, it was suggested, would be nomination by the Commission and a decision by the Council under qualified majority. The office holder could have a non-renewal term of six years. The follow-up study of 2000 in particular stressed at length the need to adopt an EPP, because of inter alia the complexity of horizontal cooperation, the diversity of competent authorities, the heterogeneous nature of legal instruments, the diversity of rules of evidence and the lack of admissibility of rules obtained abroad. Some of these issues have now been dealt with outside the sphere of the EPP project through mutual recognition instruments, as we shall see.

Whilst the Corpus Juris envisaged a vertical solution, horizontal cooperation instruments based on mutual recognition (such as the European Arrest Warrant) started being adopted. This means that the resolution to the EPPO conundrum is unlikely to be resolved on purely orthodox, vertical or horizontal lines: a mix can be expected.

The Commission itself first mooted the idea of an EPP in 2000, stating that some harmonisation of criminal law would be necessary, although the proposal was not taken up in the Treaty of Nice. In 2001 a Commission Green Paper on the criminal law protection of the financial interests of the Community and the establishment of a European Prosecutor was published (Commission of the European Communities, (2001), Green Paper on criminal protection of the financial interests of the Community and the establishment of a European Prosecutor, 11 December, COM (2001) 715). The EPP proposal was controversial from the beginning because several Member States felt that such a post would undermine national sovereignty in justice matters. Some also felt that there were problems of accountability and of ensuring a fair trial for the accused and doubted the utility of the post.

In 2003 a follow-up report summarised responses from the EU Member States to the Green Paper (Commission of the European Communities, (2003), Follow-up report on the Green Paper on criminal protection of the financial interests of the Community and the establishment of a European Prosecutor, 19 March, $\operatorname{COM}(2003) 128)$. At that time, Belgium, Greece, The Netherlands, Portugal and Spain were in favour of a European Public Prosecutor, whilst Austria, Denmark, Finland, France, Ireland and the United Kingdom were opposed. The remaining Member States including Germany, Italy, Luxembourg and Sweden had their doubts.

In 2005 the proposed Constitutional Treaty contained a provision enabling the Council to set up a European Public Prosecutor by means of a unanimous decision. The remit of the EPP would initially be limited to "combating crimes affecting the financial interests of the Union" (http://www.euractiv.com/en/future-eu/constitutionaltreaty-key-elements-archived/article-128513) However, the proposed Constitutional Treaty never came into force and the wording was amended in the Lisbon Treaty.

The Stockholm Programme mentions the EPPO in its part on criminal law:

In the field of judicial cooperation, the European Council emphasises the need for Member States and Eurojust to implement thoroughly Council Decision 2009/426/JHA of 16 December 2008 on the strengthening of Eurojust, which, together with the Lisbon Treaty, offers an opportunity for the 
further development of Eurojust in the coming years, including in relation to initiation of investigations and resolving conflicts of competence. On the basis of an assessment of the implementation of this instrument, new possibilities could be considered in accordance with the relevant provisions of the Treaty, including giving further powers to the Eurojust national members, reinforcement of the powers of the College of Eurojust or the setting-up of a European Public Prosecutor (The Stockholm Programme - An open and secure Europe serving and protecting citizens, OJ C (2010) 115, point 3.1.1, p 13)

Its action plan foresees a legislative proposal for a regulation providing Eurojust with powers to initiate investigations, making Eurojust's internal structure more efficient and involving the European Parliament and national Parliaments in the evaluation of Eurojust's activities by 2012, to be followed by a Communication on the establishment of a European Public Prosecutor's Office from Eurojust by 2013.

The House of Lords perceived a disparity between the Stockholm Programme and its action plan. The following is taken from House of Lords, (2011), The Select Committee on the European Union, Sub-Committee F (Home Affairs), "Implementation of the Stockholm Programme, Transcript of Evidence session no 1", Wednesday 13 October 2010. The evidence was given by James Brokenshire, MP, Parliamentary Under-Secretary of State and Minister for Crime Prevention, Home Office:

The Stockholm Programme was agreed by the European Council in 2009 and the Commission was invited to present an action plan in order to translate the aims and priorities of the programme into concrete points. As is made clear in the Government's explanatory memorandum on the action plan, we believe that there are a number of aspects in which the action plan differs markedly form the agreed Stockholm Programme. It was because of this disparity that the Government signed up to the Council conclusions on the Stockholm Action Plan in June. These conclusions, as you will be aware, propose only those actions that fully conform to the Stockholm Programme. The conclusions in many ways sent a clear message to the Commission: that it should not underline the role of national governments in setting the agenda for the $E U$ work on justice and home affairs by departing from the decisions of heads of government.

In 2010 the European Parliament called on the Commission to consult interested stakeholders, including civil society, on all aspects related to the creation of an EPPO for combating crimes affecting the financial interests of the European Union and to step up the adoption of all necessary measures for establishing this office (European Parliament, (2010), Resolution of 6 May 2010 on the protection of the Community's financial interests and the fight against fraud) The same year the European Commission presented a reflection paper on the reform of OLAF to the European Parliament's budgetary control committee, which mentioned that the EPPO and the consolidation of the existing anti-fraud legislation needed a thorough impact assessment.

\section{SUBSEQUENT DEVELOPMENTS}

Since the original model for European Public Prosecution was formulated in 1997, European criminal law has progressed. The EU now has a European Arrest Warrant and a European Evidence Warrant, even if the latter is restricted in functionality. More convergence is expected with a European Investigation Order (see for example J Blackstock, (2010), The European Investigation Order, New Journal of European Criminal Law, vol 1, 4, 481-98; A Farries, (2010), "The European Investigation Order, Stepping forward with care,", New Journal of European Criminal Law, vol 1, 4, 425-32) and a set of EU procedural rights. For further information, see S White, (2010), "The EU's accession to the Convention on Human Rights: A new era of closer cooperation between the Council of Europe and the EU?", NJECL, 04, pp 425-32; T. Lock, (2011), "A critical account of the accession of the European Union to the European Convention on Human Rights, JUSTICE journal, vol 8, no 2, pp 11-30; S White, (2011), "Accession of the European Union to the European Convention on Human Rights", JUSTICE journal, vol 8, no 2, pp 58-70). ${ }^{1}$

The Charter of EU Fundamental Rights is now an integral part of the EU Treaty and the EU is on the road to becoming a party to the European Convention on Human Rights. European criminal law has progressed through mutual recognition, buttressed by harmonisation whenever necessary. It has been argued that harmonisation was necessary to create the conditions of mutual trust necessary to the smooth functioning of mutual recognition.

It could therefore be argued that any proposal for the creation of an EPPO should take into account the mutual recognition acquis, which did not exist when the Corpus Juris study was first conceived. A fresh perspective is needed, which arguably obviates the need for the "two hats" approach adopted in the original Corpus Juris study. Some learned commentators have argued that the harmonisation of criminal law is needed to go much further in the context of Article 86 (see for example K Ligeti, (2011), "The European Public Prosecutor's Office: How should the rules applicable to its procedure be determined?", EuCLR 123-48). Article 86(3) states that regulations will determine the general rules applicable to the European Public Prosecutor's Office, the conditions governing the performance of its functions, the rules of procedure applicable to its activities, as well as those governing the admissibility of evidence and the rules applicable to the judicial review of procedural measures taken by it in the performance of its functions. A revised proposal for a Directive on the criminal law protection of the EU financial interests under Article 325(4) TFEU may help to make progress on this count. With a decentralised EPPO, 
the rules applicable concerning the admissibility of evidence and the procedural review of procedural measures could continue to be the rules adopted under mutual recognition. In that model, the adoption of measures such as the European Investigation Order would play an important role. But would this be enough to make enough of a difference to the practical functioning of anti-fraud investigations and prosecution?

\section{A DECENTRALISED EUROPEAN PUBLIC PROSECUTORS' (PLURAL) OFFICE?}

A European Parliament study has suggested that the EPPO would act as a complementary judicial body when the Member States authorities fail to carry out their role (European Parliament Study, Directorate-General for Internal Policies Policy Department Budgetary Affairs, (2011), Improving coordination between the EU bodies competent in the area of police and judicial cooperation: moving towards a European Prosecutor, p 38). However, complementarity might well turn out to be as slippery a concept as subsidiarity, at least in this context. Furthermore it can only be applied in terms of a purely vertical model (as set out in the Corpus Juris). This assumes that instances of neglect of duty by national authorities would be reported to a central EPPO, who would then instruct decentralised delegated prosecutors to take action, on the basis of an agreed definition of complementarity.

There is the stumbling block: instruct. It is difficult to see how this would be conducive to good relations in (what Zwiers has rightly called) a multilevel criminal justice system.

Perhaps a flatter structure - more cooperative and (in operational terms) more integrated - could do more to encourage the protection of the financial interests of the EU (model 2 in Table 1). Heads of (relevant) prosecution services in the Member States could be designated as the national member of the EPPO (henceforth NEPPs). They would be given a specific responsibility for the protection of the EU financial interests by their governments according to a definition of "protection of the financial interests of the EU" (as agreed in the Council of the European Union under Art 325 TFEU).

Such an arrangement would overcome the potential weakness of designating national staff who do not have effective command over all the resources that might be needed. The important thing is not to detach the European and national levels and resources.

Each head of national prosecution services/national EPP (NEPP) would no doubt wish to designate a Deputy and a staff to hold responsibilities on a day-to-day basis. The latter would maintain face to face relations with top-level prosecutors/managers, who have to implement decisions to prosecute. The legal obligation would remain with the NEPPs for investigation and prosecution, which would mean that all national resources would fall to the task. This would be in keeping with Article 85, which requires that prosecutions be carried out by national prosecution authorities.

There is no reason why the heads, deputies and staff should not have a desk in a central office (the EPPO in a physical sense), however at other times they could communicate with their peers in other Member States by secure telephone, messaging systems and - when needed for clarification of issues - by video conferencing. A central office could of course exist. It might share a secretariat with Eurojust and the European Judicial Network, at least initially, and could be chaired in the administrative sense by the EU Member States on a rotating basis.

This could be seen more as an adaptation to the progress of mutual recognition, an application of subsidiarity and an accommodation to the present times of austerity: a proposal for setting up a new, fully-fledged European institution setting up a new, vertical cooperation is likely to be met (at best) with gritted teeth at the political level. Progression to a "vertical" EPPO (model 3 in Table 1) could be considered in time, based on the progress of a NEPP. If so, the EPPO could build upon the NEPPs' experience of investigations and prosecutions using the resources of the Member States.

It might be objected that an arrangement would have consequences differing little from the present situation, in which - some of those active in the institutions - EU frauds are not taken as seriously as national frauds. That however is to misunderstand the situation on two levels. First, as practitioners know, it is frauds in general (ie, including frauds at national level) that are not always taken as seriously as other issues. This needs to be addressed and can be, through the present proposal. By conjoining the prosecution resources applied to national and to EU frauds, and by signally the political importance of both, more vigorous action would be encouraged on both fronts. The path signalled here could have the advantage of highlighting and energising anti-fraud work in general. That could only be for the good, both in operational terms and as a step towards steps, as outlined above.

Second, any division of operational work into separate agencies, arranged at different "levels", is simply asking for inefficiency, misunderstandings and delay. Better to contract the levels into just one; and that is most simply done by building on what is already there.

\section{CONCLUSION: PROGRESSIVE IMPLEMENTATION OF ARTICLES 85 AND 86 TFEU}

After Lisbon, the debate remains fluid. Suggestions for models include:

(i) a progressive transformation of Eurojust, given the existing college and its national members more powers; 
(ii) the creation of an EPPO distinct from Eurojust but using Eurojust expertise;

(iii) the creation of an EPPO as a specialised unit within Eurojust and

(iv) a merger of Eurojust and the EPPO, with their respective decision-making mechanisms.

The Bruges Seminar - a strategic seminar called "Eurojust and the Lisbon Treaty: towards more effective action' - was organised by Eurojust in cooperation with the Belgian Presidency of the Council of the European Union. It was held in Bruges, Belgium from 20-22 September 20-22, 2010 and possible scenarios for the organisation of the EPPO and its relationship with Euro just were discussed in workshop 6. Some possible combinations were suggested: the EPPO could sit in the Eurojust College whenever matters related to the protection of the financial interests of the Union are discussed or nine national members from the participating states could become deputy European Public Prosecutors. The EPPO could also work as a "mini college." The suggestions are legion.

This paper has suggested that, in order to make practical progress, two questions need to be untangled: a legal and political question about the relations between Articles 85 and 86; and a question that is also of course legal and political, but also is more practically focussed, on effective use by the EEPO of national investigative and prosecution resources.

This paper has argued that Articles 85 and 86 TFEU allow for the possibility for a staged development of the investigation and prosecution of crimes to the detriment of the financial interests of the EU. Thus, it may be possible to start off by a reinforcement of Eurojust, whilst the legal instruments deemed to be necessary are being adopted.

Further progress and the adoption of the European Investigation Order, in particular, may then make it possible to extend an Article 85-based EPPO to an Article 86 based EPPO with a wider competence. Article 86(4) TFEU states that the European Council may adopt a decision amending in order to extend the powers of the European Public Prosecutor's Office to include serious crime having a cross-border dimension. The European Council would act unanimously after obtaining the consent of the European Parliament and after consulting the Commission.

Alternatively, action under Article 85 could drive in the direction of a decentralised EPP, constituted by heads of national prosecution services. Designating them as national EPPs (NEPPs) would most directly lend all the resources they command to the protection of the financial interests of the EU. Implementing such a strategy would require some thought, especially considering the variations in structure, governance, accountability and occupational culture of the prosecution services with Member States. However it might turn out to be a quite direct route to applying national prosecution (and by implication investigation) resources to the protection of EU financial interests. Decentralisation is discussed and indeed implemented in some other areas of EU policy (think for example of competition) and there seems no reason not to consider it here, alongside proposals for a centralised EPPO and the 'half-way house' that could be offered by Eurojust.

- This article reflects on and extends some of the issues raised at an IALS seminar held on December 12, 2011. Speakers included Aled Williams, Chairman of Eurojust; Peter Csonka, DG JUST European Commission; Professor John Spencer, Selwyn College Cambridge and Chair of the UK European Criminal Law Association; Professor Katalina Ligeti and Valentina Covolo, Department of Law at the University of Luxembourg; and Dr Simone White.

\section{Simone White}

The author is a Legal Officer in OLAF, the Anti-Fraud Office of the European Commission, and an Associate Research Fellow at IALS. The views contained in this article are not intended to represent those of the European Commission. She is the author of a number of articles and books on the $E U$ and on the protection of its financial interests, most recently OLAF at the crossroads (Hart Publishing, 2011, with Stefanou and Xanthaki). The authors thank Jan Inghelram, Lothar Kuhl and Hans Nilsson for their comments on a draft.

\section{Nicholas Dorn}

Professor at the Erasmus School of Law, Rotterdam. 